\title{
Synthesis and characterization of the tetranuclear iron(III) complex of a new asymmetric multidentate ligand. A structural model for purple acid phosphatases $\uparrow$
}

\author{
Athanassios K. Boudalis, ${ }^{b}$ Robyn E. Aston, ${ }^{a}$ Sarah J. Smith, ${ }^{a}$ Ruth E. Mirams, ${ }^{a}$ Mark J. Riley, ${ }^{a}$ \\ Gerhard Schenk, ${ }^{a}$ Allan G. Blackman, ${ }^{c}$ Lyall R. Hanton ${ }^{c}$ and Lawrence R. Gahan ${ }^{a}$
}

Received 19th June 2007, Accepted 21st August 2007

First published as an Advance Article on the web 6th September 2007

DOI: 10.1039/b709293h

\begin{abstract}
The ligand, 2-((2-hydroxy-5-methyl-3-((pyridin-2-ylmethylamino)methyl)benzyl)(2-hydroxybenzyl)amino)acetic acid ( $\left.\mathrm{H}_{3} \mathrm{HPBA}\right)$, which contains a donor atom set that mimics that of the active site of purple acid phosphatase is described. Reaction of $\mathrm{H}_{3}$ HPBA with iron(III) or iron(II) salts results in formation of the tetranuclear complex, $\left[\mathrm{Fe}_{4}(\mathrm{HPBA})_{2}(\mathrm{OAc})_{2}(\mu-\mathrm{O})(\mu-\mathrm{OH})\left(\mathrm{OH}_{2}\right)_{2}\right] \mathrm{ClO}_{4} \cdot 5 \mathrm{H}_{2} \mathrm{O}$. X-Ray structural analysis reveals the cation consists of four iron(III) ions, two HPBA ${ }^{3-}$ ligands, two bridging acetate ligands, a bridging oxide ion and a bridging hydroxide ion. Each binucleating $\mathrm{HPBA}^{3-}$ ligand coordinates two structurally distinct hexacoordinate iron(III) ions. The two metal ions coordinated to a $\mathrm{HPBA}^{3-}$ ligand are linked to the two iron(III) metal ions of a second, similar binuclear unit by intramolecular oxide and hydroxide bridging moieties to form a tetramer. The complex has been further characterised by elemental analysis, mass spectrometry, UV-vis and MCD spectroscopy, X-ray crystallography, magnetic susceptibility measurements and variable-temperature Mössbauer spectroscopy.
\end{abstract}

\section{Introduction}

The synthesis of di- and tetra-iron species with oxo, hydroxo and $\mathrm{OHO}^{3-}$ bridges is of interest as such complexes can potentially serve as structural models of the active sites of iron-containing metallobiosites such as methane monooxygenase, ribonucleotide reductase, purple acid phosphatases and ferritin, as well as the oxygen evolving proteins. ${ }^{1-9}$

Our principal interest is in systems which model the active sites of metallohydrolases, ${ }^{10}$ of which the purple acid phosphatases (PAPs) are prototypical. ${ }^{10-14}$ More generally, we are interested in ligand systems with the ability to assemble Fe(III) clusters with relevance to the build up of iron-oxo cores. ${ }^{15}$ Thus, we have previously investigated the synthesis of ligand systems leading to diiron(III), diiron(II) ${ }^{16}$ and tetrairon(III) ${ }^{15}$ complexes and the potential relevance of these complexes to metallobiosites.

PAPs are the only binuclear metallohydrolases where the necessity for a heterovalent active site (Fe(III)-M(II), where $\mathrm{M}=\mathrm{Fe}, \mathrm{Zn}$ or $\mathrm{Mn}$ ) for catalysis has been established. ${ }^{10-14}$ PAPs catalyse the hydrolysis of a broad range of phosphorylated substrates at acidic to neutral $\mathrm{pH}$. The enzyme isolated from mammalian organisms (pig, bovine, mouse, rat and human) is a $\sim 35 \mathrm{kDa}$ monomeric protein with an $\mathrm{Fe}(\mathrm{III})-\mathrm{Fe}(\mathrm{II})$ centre; the amino acid sequences of animal PAPs are highly conserved with at least $85 \%$ identity. ${ }^{17-19}$

${ }^{a}$ School of Molecular and Microbial Sciences, The University of Queensland, QLD, Australia 4072

"Institute of Materials Science, NCSR "Demokritos", 15310, Aghia Paraskevi Attikis, Greece

'Department of Chemistry, Te Tari Hua-Ruanuku, University of Otago, PO Box 56, Dunedin, New Zealand

$\dagger$ CCDC reference number 651214. For crystallographic data in CIF or other electronic format see DOI: 10.1039/b709293h
The iron(III) is coordinated to the oxygen of a tyrosine, the nitrogen atom of a histidine and the oxygen atoms of two aspartate residues, one of which bridges the two metal sites, a $\mu$-hydroxo and a putative terminal hydroxo/aqua ligand. The divalent metal ion is coordinated to the oxygen atom of the bridging aspartate, the nitrogen atoms of two histidine residues, an asparagine oxygen, the $\mu$-hydroxo and a putative aqua ligand. The enzyme thus provides an asymmetric binuclear active site with a hard $\mathrm{NO}_{5}$ $\mathrm{Fe}$ (III) site and a somewhat softer $\mathrm{N}_{2} \mathrm{O}_{4}$ divalent metal site (Fig. 1). The number of terminal and bridging aqua/hydroxo ligands is ambiguous; available crystal structures provide conflicting data ${ }^{20,21}$ but spectroscopic data for the pig enzyme indicate that in the resting state the iron(III) is pentacoordinate with only a bridging hydroxo/aqua and a terminal iron(II)-bound aqua ligand present in the active site. ${ }^{22}$ The characteristic colour of PAPs is due to



Fig. 1 Schematic illustration of the $\mathrm{Fe}^{\mathrm{III}}-\mathrm{Fe}^{\mathrm{II}}$ uteroferrin active site. Note that crystallographic data have only been obtained for the oxidized $\mathrm{Fe}^{\mathrm{III}}-\mathrm{Fe}^{\mathrm{III}}$ form. ${ }^{17}$ 
a charge transfer transition $\left(\lambda_{\max }=510-560 \mathrm{~nm} ; \varepsilon=\sim 3000\right.$ $4000 \mathrm{M}^{-1} \mathrm{~cm}^{-1}$ ) in the active site from a conserved tyrosine ligand to the ferric ion. Mammalian PAPs can easily (and reversibly) be oxidized to the inactive di-ferric form due to the low redox potential $(\sim 340 \mathrm{mV})$ of the divalent iron. ${ }^{23,24}$

We report herein the synthesis and characterization of a new unsymmetrical binucleating ligand methyl 2-((2-hydroxy-5-methyl3-((pyridin-2-ylmethylamino)methyl)benzyl)(2-hydroxybenzyl)amino)acetate $\left(\mathrm{H}_{2} \mathrm{HPBMA}\right)$, and the corresponding acid, methyl 2-((2-hydroxy-5-methyl-3-((pyridin-2-ylmethylamino)methyl)benzyl)(2-hydroxybenzyl)amino)acetic acid $\left(\mathrm{H}_{3} \mathrm{HPBA}\right)$ (Fig. 2). The formation of a tetrairon(III) complex and its characterization is reported, as well as the relevance of its dimeric units as a structural model of the oxidized form of mammalian PAP.

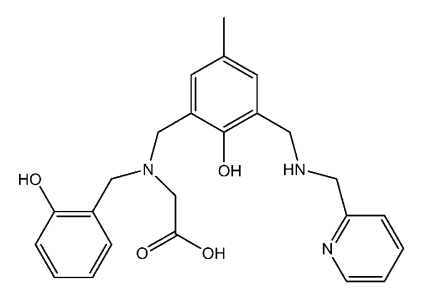

$\mathrm{H}_{3} \mathrm{HPBA}$

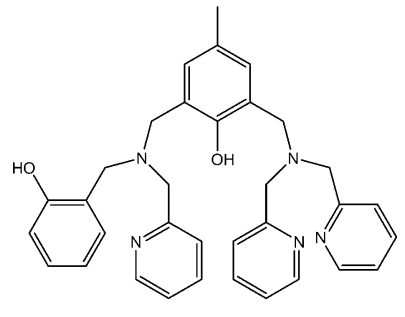

$\mathrm{H}_{2}$ BPBPMP

Fig. $2 \mathrm{H}_{3}$ HPBA and $\mathrm{H}_{2}$ BPBPMP.

\section{Results and discussion}

\section{Synthesis of the ligand and complex}

The methyl ester $\mathrm{H}_{2}$ HPBMA was produced in a reaction sequence (Scheme 1) involving the stepwise addition of $N$-(2hydroxybenzyl)glycine ethyl ester and 2-aminomethylpyridine to 2-hydroxy-3-chloromethyl-5-methylbenzaldehyde with sub-
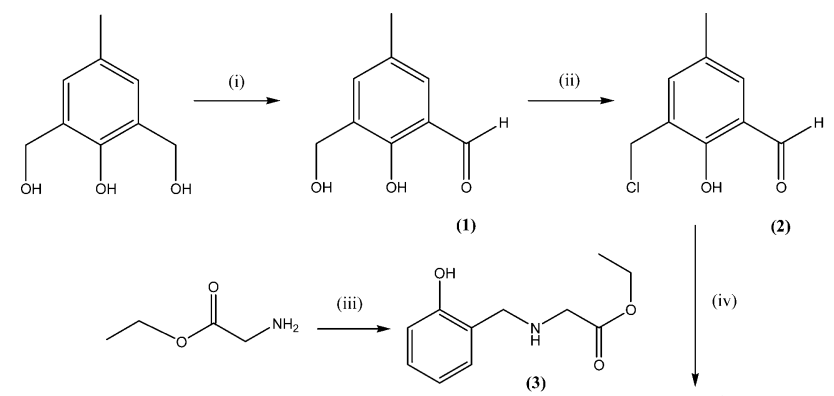

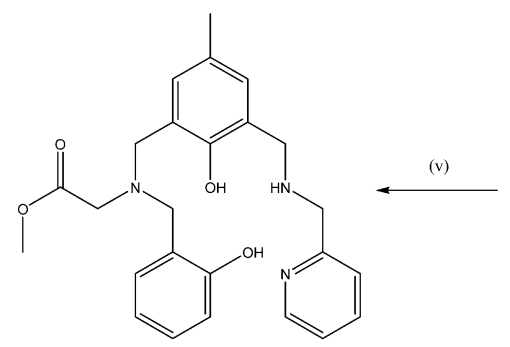

$\mathrm{H}_{2}$ HPBMA

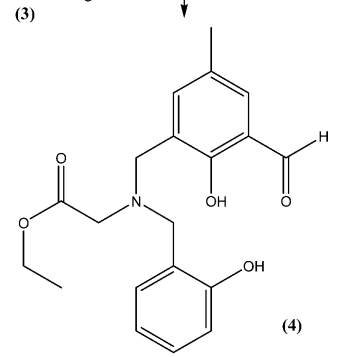

(4)

Scheme 1 Synthesis of $\mathrm{H}_{2} \mathrm{HPBMA}$; (i) $\mathrm{MnO}_{2}$; (ii) conc. $\mathrm{HCl}$; (iii) salicylaldehyde- $\mathrm{NaBH}_{4}$; (iv) (2) + (3); (v) (4) + 2-aminomethylpyridine, $\mathrm{NaBH}_{4}$, methanol. sequent reduction of the imine with sodium borohydride. Transesterification at the borohydride step resulted in the isolation of the pure methyl ester after column chromatography. The ligand was characterised by NMR and MS. The ligand can be considered as an analogue of 2-bis[\{(2-pyridyl-methyl)-aminomethyl $\}$-6$\{(2$-hydroxybenzyl)-(2-pyridyl-methyl) $\}$-aminomethyl]-4-methylphenol $\left(\mathrm{H}_{2} \text { BPBPMP; Fig. } 2\right)^{25}$ which when complexed with two metal ions in the presence of acetate, furnishes a ( $\mu$-phenoxo)bis $(\mu$-carboxylato $)$ core with a soft site $\left(\mathrm{N}_{3} \mathrm{O}_{3}\right)$ and a harder site $\left(\mathrm{N}_{2} \mathrm{O}_{4}\right)$ mimicking the soft and hard sites of the pig PAP enzyme. ${ }^{25}$ In the case of $\mathrm{H}_{3} \mathrm{HPBA}$ the inclusion of a glycine moiety mimics the asparagine residue.

Reaction of a $2: 1: 3$ stoichiometric ratio of ferrous chloride, $\mathrm{H}_{2}$ HPBMA and sodium acetate in aqueous basic methanol resulted in hydrolysis of the ester and, upon standing in the presence of perchlorate anion, dark purple crystals were isolated. These were subsequently identified as the tetrameric iron(III) complex $\left[\mathrm{Fe}_{4}(\mathrm{HPBA})_{2}(\mathrm{OAc})_{2}(\mu-\mathrm{O})(\mu-\mathrm{OH})\left(\mathrm{OH}_{2}\right)_{2}\right] \mathrm{ClO}_{4} \cdot 5 \mathrm{H}_{2} \mathrm{O}$.

\section{Description of the structure}

Crystals of the complex contain a discrete $\left[\mathrm{Fe}_{4}(\mathrm{HPBA})_{2}(\mathrm{OAc})_{2}(\mu\right.$ $\left.\mathrm{O})(\mu-\mathrm{OH})\left(\mathrm{OH}_{2}\right)_{2}\right]^{+}$cation and a disordered perchlorate anion. Although the microanalytical data suggested that the bulk crystalline sample crystallised with eight waters of crystallisation, the sample employed for structural analysis, Mössbauer and magnetic studies contained only five water molecules. An ORTEP diagram of the complex cation is shown in Fig. 3; crystal data are listed in Table 1 with important bond distance and angles information listed in Table 2 .

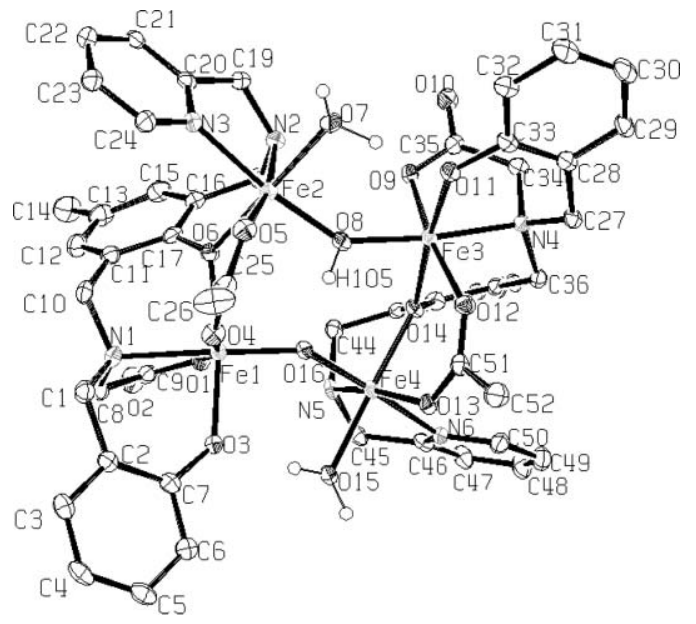

Fig. 3 An ORTEP plot of the complex cation of $\left[\mathrm{Fe}_{4}(\mathrm{HPBA})_{2}(\mu\right.$ $\left.\mathrm{O})(\mu-\mathrm{OH})(\mathrm{OAc})_{2}\left(\mathrm{OH}_{2}\right)_{2}\right] \mathrm{ClO}_{4} \cdot 5 \mathrm{H}_{2} \mathrm{O}$ determined at $89 \mathrm{~K}$. Thermal probability ellipsoids are drawn at the $50 \%$ probability level.

The cation consists of a ( $\mu$-охо)( $\mu$-hydroxo)-bridged dimer of $\left[\mathrm{Fe}_{2}(\mathrm{HPBA})(\mathrm{OAc})\left(\mathrm{OH}_{2}\right)\right]^{2+}$ dimers. Each HPBA ${ }^{3-}$ ligand coordinates two structurally distinct six-coordinate iron(III) sites bridged by an acetate ligand, in the typical $\eta^{1}: \eta^{1}: \mu_{2}$ arrangement, and a $\mu$-phenoxo bridge. The $\mathrm{NO}_{5}$ coordination environments of $\mathrm{Fe}(1)$ and $\mathrm{Fe}(3)$ are composed of oxygen donors from the monodentate phenolate and $\mu$-phenolate, the carboxylate, the $\mu$-acetate and the tertiary nitrogen donor; the sixth coordination position for $\mathrm{Fe}(1)$ is the $\mu$-oxo ligand and for $\mathrm{Fe}(3)$ the $\mu$-hydroxo ligand. The $\mathrm{N}_{2} \mathrm{O}_{4}$ 
Table 1 Crystallographic data for $\left[\mathrm{Fe}_{4}(\mathrm{HPBA})_{2}(\mu-\mathrm{O})(\mu-\mathrm{OH})(\mathrm{OAc})_{2}\right.$ $\left.\left(\mathrm{OH}_{2}\right)_{2}\right] \mathrm{ClO}_{4} \cdot 5 \mathrm{H}_{2} \mathrm{O}$

$\begin{array}{ll}\text { Empirical formula } & \mathrm{C}_{52} \mathrm{H}_{69} \mathrm{ClFe}_{4} \mathrm{~N}_{6} \mathrm{O}_{25} \\ \text { Formula weight } & 1436.14 \\ \text { Temperature/K } & 89(2) \\ \text { Crystal system } & \text { Monoclinic } \\ \text { Space group } & P 2_{1} / c \\ a / \AA & 22.667(5) \\ b / \AA & 11.552(5) \\ c / \AA & 24.952(5) \\ \beta /^{\circ} & 111.076(5) \\ \text { Volume/ } \AA^{3} & 6097 \\ \text { Absorption coefficient/mm } & -1 \\ \text { Reflections collected/unique } & 1.603 \\ \text { Data/restraints/parameters } & 56356 / 10796\left(R_{\text {int }}=0.0500\right) \\ \text { Final } R \text { indices }[I>2 \sigma(I)] & 10796 / 0 / 845 \\ R \text { indices (all data) } & R=0.0585, R_{\mathrm{w}}=0.840 \\ & R=0.1447, R_{\mathrm{w}}=0.1608\end{array}$

Table 2 Selected bond lengths $(\AA)$ and angles $\left(^{\circ}\right)$ for $\left[\mathrm{Fe}_{4}(\mathrm{HPBA})_{2}(\mu\right.$ $\left.\mathrm{O})(\mu-\mathrm{OH})(\mathrm{OAc})_{2}\left(\mathrm{OH}_{2}\right)_{2}\right] \mathrm{ClO}_{4} \cdot 5 \mathrm{H}_{2} \mathrm{O}$

\begin{tabular}{|c|c|c|c|}
\hline $\mathrm{Fe}(1)-\mathrm{O}(16)$ & $1.841(4)$ & $\mathrm{Fe}(1)-\mathrm{O}(3)$ & $1.957(4)$ \\
\hline $\mathrm{Fe}(1)-\mathrm{O}(4)$ & $2.022(4)$ & $\mathrm{Fe}(1)-\mathrm{O}(1)$ & $2.060(4)$ \\
\hline $\mathrm{Fe}(1)-\mathrm{O}(6)$ & $2.117(4)$ & $\mathrm{Fe}(1)-\mathrm{N}(1)$ & $2.209(5)$ \\
\hline $\mathrm{Fe}(3)-\mathrm{O}(8)$ & $1.909(4)$ & $\mathrm{Fe}(3)-\mathrm{O}(11)$ & $1.941(4)$ \\
\hline $\mathrm{Fe}(3)-\mathrm{O}(9)$ & $2.008(4)$ & $\mathrm{Fe}(3)-\mathrm{O}(12)$ & $2.017(4)$ \\
\hline $\mathrm{Fe}(3)-\mathrm{O}(14)$ & $2.070(4)$ & $\mathrm{Fe}(3)-\mathrm{N}(4)$ & $2.186(4)$ \\
\hline $\mathrm{Fe}(4)-\mathrm{O}(16)$ & $1.819(4)$ & $\mathrm{Fe}(4)-\mathrm{O}(13)$ & $1.994(4)$ \\
\hline $\mathrm{Fe}(4)-\mathrm{O}(14)$ & $2.047(4)$ & $\mathrm{Fe}(4)-\mathrm{O}(15)$ & $2.056(4)$ \\
\hline $\mathrm{Fe}(4)-\mathrm{N}(5)$ & $2.177(4)$ & $\mathrm{Fe}(4)-\mathrm{N}(6)$ & $2.202(4)$ \\
\hline $\mathrm{Fe}(2)-\mathrm{O}(8)$ & $1.884(4)$ & $\mathrm{Fe}(2)-\mathrm{O}(5)$ & $1.977(4)$ \\
\hline $\mathrm{Fe}(2)-\mathrm{O}(6)$ & $2.008(4)$ & $\mathrm{Fe}(2)-\mathrm{O}(7)$ & $2.045(4)$ \\
\hline $\mathrm{Fe}(2)-\mathrm{N}(3)$ & $2.126(5)$ & $\mathrm{Fe}(2)-\mathrm{N}(2)$ & $2.161(5)$ \\
\hline $\mathrm{O}(16)-\mathrm{Fe}(1)-\mathrm{O}(3)$ & $94.67(16)$ & $\mathrm{O}(16)-\mathrm{Fe}(1)-\mathrm{O}(4)$ & $100.15(16$ \\
\hline $\mathrm{O}(3)-\mathrm{Fe}(1)-\mathrm{O}(4)$ & $92.36(16)$ & $\mathrm{O}(16)-\mathrm{Fe}(1)-\mathrm{O}(1)$ & $92.89(16$ \\
\hline $\mathrm{O}(3)-\mathrm{Fe}(1)-\mathrm{O}(1)$ & $91.71(15)$ & $\mathrm{O}(4)-\mathrm{Fe}(1)-\mathrm{O}(1)$ & $165.97(15$ \\
\hline $\mathrm{O}(16)-\mathrm{Fe}(1)-\mathrm{O}(6)$ & $92.88(15)$ & $\mathrm{O}(3)-\mathrm{Fe}(1)-\mathrm{O}(6)$ & $172.30(15)$ \\
\hline $\mathrm{O}(4)-\mathrm{Fe}(1)-\mathrm{O}(6)$ & $84.82(15)$ & $\mathrm{O}(1)-\mathrm{Fe}(1)-\mathrm{O}(6)$ & $89.41(15)$ \\
\hline $\mathrm{O}(16)-\mathrm{Fe}(1)-\mathrm{N}(1)$ & $171.14(17)$ & $\mathrm{O}(3)-\mathrm{Fe}(1)-\mathrm{N}(1)$ & $84.71(16$ \\
\hline $\mathrm{O}(4)-\mathrm{Fe}(1)-\mathrm{N}(1)$ & $88.71(16)$ & $\mathrm{O}(1)-\mathrm{Fe}(1)-\mathrm{N}(1)$ & $78.30(16)$ \\
\hline $\mathrm{O}(6)-\mathrm{Fe}(1)-\mathrm{N}(1)$ & $88.06(16)$ & $\mathrm{O}(8)-\mathrm{Fe}(3)-\mathrm{O}(11)$ & $92.87(17)$ \\
\hline $\mathrm{O}(8)-\mathrm{Fe}(3)-\mathrm{O}(9)$ & $91.22(16)$ & $\mathrm{O}(11)-\mathrm{Fe}(3)-\mathrm{O}(9)$ & $92.25(16)$ \\
\hline $\mathrm{O}(8)-\mathrm{Fe}(3)-\mathrm{O}(12)$ & $98.30(17)$ & $\mathrm{O}(11)-\mathrm{Fe}(3)-\mathrm{O}(12)$ & $88.55(16)$ \\
\hline $\mathrm{O}(9)-\mathrm{Fe}(3)-\mathrm{O}(12)$ & $170.39(16)$ & $\mathrm{O}(8)-\mathrm{Fe}(3)-\mathrm{O}(14)$ & $90.42(16)$ \\
\hline $\mathrm{O}(11)-\mathrm{Fe}(3)-\mathrm{O}(14)$ & $174.95(16)$ & $\mathrm{O}(9)-\mathrm{Fe}(3)-\mathrm{O}(14)$ & $91.51(15)$ \\
\hline $\mathrm{O}(12)-\mathrm{Fe}(3)-\mathrm{O}(14)$ & $87.19(15)$ & $\mathrm{O}(8)-\mathrm{Fe}(3)-\mathrm{N}(4)$ & $171.08(17)$ \\
\hline $\mathrm{O}(11)-\mathrm{Fe}(3)-\mathrm{N}(4)$ & $88.33(16)$ & $\mathrm{O}(9)-\mathrm{Fe}(3)-\mathrm{N}(4)$ & $79.90(16)$ \\
\hline $\mathrm{O}(12)-\mathrm{Fe}(3)-\mathrm{N}(4)$ & $90.55(16)$ & $\mathrm{O}(14)-\mathrm{Fe}(3)-\mathrm{N}(4)$ & $89.01(15)$ \\
\hline $\mathrm{O}(16)-\mathrm{Fe}(4)-\mathrm{O}(13)$ & $101.15(16)$ & $\mathrm{O}(16)-\mathrm{Fe}(4)-\mathrm{O}(14)$ & $93.40(16)$ \\
\hline $\mathrm{O}(13)-\mathrm{Fe}(4)-\mathrm{O}(14)$ & $91.53(15)$ & $\mathrm{O}(16)-\mathrm{Fe}(4)-\mathrm{O}(15)$ & $90.08(17)$ \\
\hline $\mathrm{O}(13)-\mathrm{Fe}(4)-\mathrm{O}(15)$ & $90.57(16)$ & $\mathrm{O}(14)-\mathrm{Fe}(4)-\mathrm{O}(15)$ & $175.52(16)$ \\
\hline $\mathrm{O}(16)-\mathrm{Fe}(4)-\mathrm{N}(5)$ & $94.31(17)$ & $\mathrm{O}(13)-\mathrm{Fe}(4)-\mathrm{N}(5)$ & $164.49(16)$ \\
\hline $\mathrm{O}(14)-\mathrm{Fe}(4)-\mathrm{N}(5)$ & $88.82(16)$ & $\mathrm{O}(15)-\mathrm{Fe}(4)-\mathrm{N}(5)$ & $88.09(17)$ \\
\hline $\mathrm{O}(16)-\mathrm{Fe}(4)-\mathrm{N}(6)$ & $171.06(16)$ & $\mathrm{O}(13)-\mathrm{Fe}(4)-\mathrm{N}(6)$ & $87.72(16)$ \\
\hline $\mathrm{O}(14)-\mathrm{Fe}(4)-\mathrm{N}(6)$ & $87.39(16)$ & $\mathrm{O}(15)-\mathrm{Fe}(4)-\mathrm{N}(6)$ & $88.74(17)$ \\
\hline $\mathrm{N}(5)-\mathrm{Fe}(4)-\mathrm{N}(6)$ & $76.80(16)$ & $\mathrm{O}(8)-\mathrm{Fe}(2)-\mathrm{O}(5)$ & $97.95(17)$ \\
\hline $\mathrm{O}(8)-\mathrm{Fe}(2)-\mathrm{O}(6)$ & $93.21(16)$ & $\mathrm{O}(5)-\mathrm{Fe}(2)-\mathrm{O}(6)$ & $90.07(15)$ \\
\hline $\mathrm{O}(8)-\mathrm{Fe}(2)-\mathrm{O}(7)$ & 87.01(19) & $\mathrm{O}(5)-\mathrm{Fe}(2)-\mathrm{O}(7)$ & $94.40(18)$ \\
\hline $\mathrm{O}(6)-\mathrm{Fe}(2)-\mathrm{O}(7)$ & $175.45(18)$ & $\mathrm{O}(8)-\mathrm{Fe}(2)-\mathrm{N}(3)$ & $171.15(18$ \\
\hline $\mathrm{O}(5)-\mathrm{Fe}(2)-\mathrm{N}(3)$ & $89.58(17)$ & $\mathrm{O}(6)-\mathrm{Fe}(2)-\mathrm{N}(3)$ & $91.42(16$ \\
\hline $\mathrm{O}(7)-\mathrm{Fe}(2)-\mathrm{N}(3)$ & $87.79(19)$ & $\mathrm{O}(8)-\mathrm{Fe}(2)-\mathrm{N}(2)$ & $94.11(18)$ \\
\hline $\mathrm{O}(5)-\mathrm{Fe}(2)-\mathrm{N}(2)$ & $167.93(17)$ & $\mathrm{O}(6)-\mathrm{Fe}(2)-\mathrm{N}(2)$ & $88.64(16)$ \\
\hline $\mathrm{O}(7)-\mathrm{Fe}(2)-\mathrm{N}(2)$ & $86.81(18)$ & $\mathrm{N}(3)-\mathrm{Fe}(2)-\mathrm{N}(2)$ & $78.45(17)$ \\
\hline $\mathrm{Fe}(2)-\mathrm{O}(6)-\mathrm{Fe}(1)$ & $121.00(17)$ & $\mathrm{Fe}(4)-\mathrm{O}(14)-\mathrm{Fe}(3)$ & $120.52(18)$ \\
\hline $\mathrm{Fe}(2)-\mathrm{O}(8)-\mathrm{Fe}(3)$ & $144.0(2)$ & $\mathrm{Fe}(1)-\mathrm{O}(16)-\mathrm{Fe}(4)$ & $146.8(2)$ \\
\hline
\end{tabular}

donor sets for $\mathrm{Fe}(2)$ and $\mathrm{Fe}(4)$ comprise an aqua ligand, the $\mu$ phenolate, $\mu$-acetate, the secondary amine and pyridine nitrogen donors; for $\mathrm{Fe}(2)$ the $\mu$-hydroxo ligand and for $\mathrm{Fe}(4)$ the $\mu$-oxo ligand complete the octahedral coordination.

The assignment of the formal $\mu$-oxo and $\mu$-hydroxo bridges was based on chemical and structural evidence. In the first instance, the charge balance required either the presence of a terminal hydroxo ligand on one of the $\mathrm{Fe}(\mathrm{III})$ sites or the presence of a $\mu$-hydroxo ligand. The terminal Fe(III)-O distances ( $\mathrm{Fe}(2)-\mathrm{O}(7), 2.045(4) \AA$; $\mathrm{Fe}(4)-\mathrm{O}(15), 2.056(4) \AA$ ) appear typical of $\mathrm{Fe}-\mathrm{OH}_{2}$ bond lengths, ${ }^{26}$ rather than $\mathrm{Fe}-\mathrm{OH}$ which may be as short as $1.804 \AA$ or as long as $1.93 \AA .{ }^{27-29}$ In addition, the $\mathrm{H}(105)$ atom was determined from the difference Fourier synthesis and appears localized on $\mathrm{O}$ (8) $(\mathrm{O}(8)-\mathrm{H}(105), 0.83 \AA)^{9}$ rather than being symmetrically located. ${ }^{9,15,30}$ The $\mu$-oxo and $\mu$-hydroxo ligands are within $\mathrm{H}$-bond distance $\left(\mathrm{O}(16) \cdots \mathrm{O}(8) ; 2.50 \AA, 179.21^{\circ}\right)$; other intramolecular $\mathrm{H}$-bonds are apparent between $\mathrm{O}(3)-\mathrm{O}(15), \mathrm{N}(5)-\mathrm{O}(1), \mathrm{N}(2)-$ $\mathrm{O}(9)$ and $\mathrm{O}(7)-\mathrm{O}(11)$ (Fig. 4). Comparison of the relative bond lengths also suggests that the interdimer bridges are different. Thus, the $\mu$-oxo-diiron(III) distances are at the long end of those typically seen for this moiety $\left(1.76-1.82 \AA\right.$ ) with $\mathrm{Fe}-\mathrm{O}_{\text {oxo }}$ distances (Fe(1)-O(16), 1.841(4) Å; Fe(4)-O(16), 1.819(4) Å, Fe(1)-O(16)$\left.\mathrm{Fe}(4), 146.8(2)^{\circ}\right)$ shorter than the $\mathrm{Fe}-\mathrm{O}_{\text {hydroxo }}$ distances $(\mathrm{Fe}(2)-\mathrm{O}(8)$, 1.884(4) $\AA$; $\left.\mathrm{Fe}(3)-\mathrm{O}(8), 1.909(4) \AA, \mathrm{Fe}(2)-\mathrm{O}(8)-\mathrm{Fe}(3), 144.0(2)^{\circ}\right)$. For $\mathrm{Fe}(\mathrm{III})-\mathrm{O}-\mathrm{Fe}(\mathrm{III})$ complexes the angles range from $114-180^{\circ}$, whilst for $\mathrm{Fe}(\mathrm{III})-\mathrm{OH}-\mathrm{Fe}(\mathrm{III})$ complexes the angles vary between $103-123^{\circ} .^{2}$ For $\left[\mathrm{Fe}_{4}(\mathrm{HPBA})_{2}(\mathrm{OAc})_{2}(\mu-\mathrm{O})(\mu-\mathrm{OH})\left(\mathrm{OH}_{2}\right)_{2}\right]^{+}$the interdimer $\mathrm{Fe}-\mathrm{O}-\mathrm{Fe}$ angles $\left(\mathrm{Fe}(2)-\mathrm{O}(8) \mathrm{H}-\mathrm{Fe}(3), 144.0(2)^{\circ}\right.$; $\mathrm{Fe}(1)-$ $\left.\mathrm{O}(16)-\mathrm{Fe}(4), 146.8(2)^{\circ}\right)$ are not significantly different. Whilst the $\mathrm{Fe}-\mathrm{O}-\mathrm{Fe}$ angle is similar to those reported for the tetrairon(III) complexes containing the $(\mathrm{O}-\mathrm{H}-\mathrm{O})^{3-}$ core $\left(138.3(1)^{\circ}\right),{ }^{9,30}$ the $\mathrm{Fe}-$ $\mathrm{OH}-\mathrm{Fe}$ angle is very different. Spectroscopic (vide infra) and crystallographic evidence suggest that at the temperatures at which the structural data were collected the hydrogen is localized on $\mathrm{O}(8)$ so that the $\mu$-oxo and $\mu$-hydroxo moieties can be considered as separate structural entities rather than $(\mathrm{O}-\mathrm{H}-\mathrm{O})^{3-},{ }^{30}$ suggesting that constraints imposed by the tetrameric structure are the cause of the unusual $\mathrm{Fe}-\mathrm{OH}-\mathrm{Fe}$ angle.

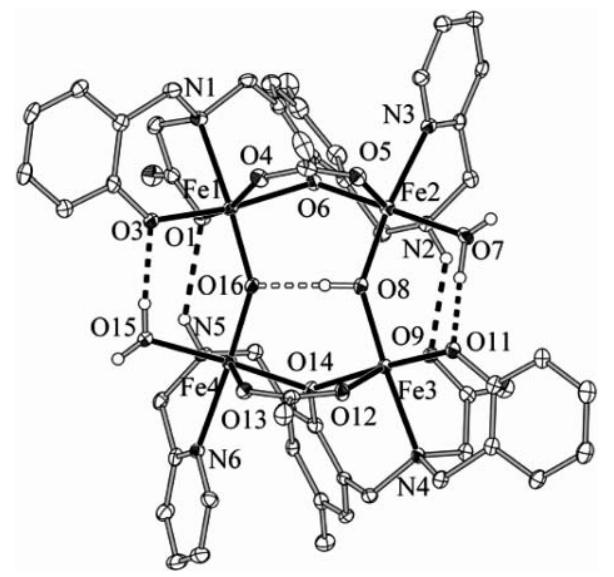

Fig. 4 H-bonding in $\left[\mathrm{Fe}_{4}(\mathrm{HPBA})_{2}(\mu-\mathrm{O})(\mu-\mathrm{OH})(\mathrm{OAc})_{2}\left(\mathrm{OH}_{2}\right)_{2}\right] \mathrm{ClO}_{4} \cdot 5 \mathrm{H}_{2} \mathrm{O}$.

The $\mu$-oxo group has a trans effect such that the Fe-N bonds trans to the oxo ligand $(\mathrm{Fe}(1)-\mathrm{N}(1) 2.209(5) \AA ; \mathrm{Fe}(4)-\mathrm{N}(6)$ 2.202(4) $\AA$ ) are longer than those trans to the $\mu$-hydroxo ligand ( $\mathrm{Fe}(2)-\mathrm{N}(3), 2.126(5) \AA$; $\mathrm{Fe}(3)-\mathrm{N}(4), 2.186(4) \AA)$ and longer than other $\mathrm{Fe}-\mathrm{N}$ bonds in the structure. The reduction in the trans 
$\mathrm{Fe}-\mathrm{N}$ bond lengths upon protonation of the $\mu$-oxo ligand has been observed previously. ${ }^{9}$ Finally, the $\mathrm{Fe}(1)-\mathrm{Fe}(4)$ interdimer separation mediated by the $\mu$-oxo bridge is $3.507 \AA$, shorter than the interdimer $\mu$-hydroxo separation, $\mathrm{Fe}(2)-\mathrm{Fe}(3)$ (3.608 $⿱$ ). By comparison, the intradimer $\mathrm{Fe}-\mathrm{Fe}$ distances ( $\mathrm{Fe}(1)-\mathrm{Fe}(2)$ and $\mathrm{Fe}(3)-\mathrm{Fe}(4))$ are $3.591 \AA$ and $3.575 \AA$, respectively. The $\left[\mathrm{Fe}_{2}(\mathrm{HPBA})(\mathrm{OAc})\left(\mathrm{OH}_{2}\right)\right]^{2+}$ dimers are thus linked asymmetrically by the interdimer $\mu$-hydroxo $\mathrm{O}(8)$ and $\mu$-oxo moieties $\mathrm{O}(16)$ resulting in the symmetry of all four $\mathrm{Fe}$ atoms being different.

The importance of the $\mu_{4}-\mathrm{OHO}^{3-}$ moiety has been noted previously, ${ }^{15,31,32}$ in particular its relevance to the oxygen-evolving $\mathrm{Mn}_{4}$ complex of photosystem II. ${ }^{9,33}$ In the previous examples, ${ }^{9,15,30}$ the $\mathrm{OHO}^{3-}$ is symmetrical, bridging the four metal ions, in contrast to the present case where the $\mathrm{H}$ atom appears localized on $\mathrm{O}(8)$.

Comparison of the binuclear cation $\left[\mathrm{Fe}_{2}(\mathrm{HPBA})(\mathrm{OAc})\left(\mathrm{OH}_{2}\right)\right]^{2+}$ with the active site of pig PAP (uteroferrin) suggests structural similarities. ${ }^{17}$ The phenolate, $\mu$-phenolate, tertiary amine and carboxylate donors of $\mathrm{HPBA}^{3-}$, the $\mu$-acetate and $\mu$-oxo, $\mathrm{O}(16)$, model the tyrosinate, $\mu-\mathrm{OH}$, the histidine and the aspartate residues, and the putative terminal hydroxide/aqua ligand, respectively, at the $\mathrm{Fe}(\mathrm{III})$ site of uteroferrin. ${ }^{17}$ The divalent metal site of uteroferrin is modeled by the secondary amine and pyridine nitrogen atoms, the $\mu$-acetate and $\mu$-phenolate, the water molecule and interdimer $\mu$-hydroxide ion. ${ }^{17}$

\section{Mass spectrometry}

High resolution ESI-MS indicates the presence of $\left[\mathrm{Fe}_{4}\right.$ $\left.(\mathrm{HPBA})_{2}(\mu-\mathrm{O})(\mu-\mathrm{OH})(\mathrm{OAc})(\mathrm{CHOO})\right]^{+} \quad(m / z$ calc 1197.1203 ; found 1197.1018), $\left[\mathrm{Fe}_{4}(\mathrm{HPBA})_{2}(\mathrm{O})_{2}(\mathrm{OAc})\right]^{+}(\mathrm{m} / z$ calc 1151.1149 ; found 1151.0961) and $\left.\left[\mathrm{Fe}_{4}(\mathrm{HPBA})_{2}\right)(\mathrm{O})_{2}(\mathrm{CHOO})\right]^{+}(\mathrm{m} / z$ calc 1137.0992; found 1137.0858). The high resolution negative ion ESI-MS suggests the presence of $\left[\mathrm{Fe}_{2}(\mathrm{HPBA})(\mathrm{OAc})(\mathrm{O})_{2}\right.$ $\left.\left(\mathrm{ClO}_{4}\right)_{2}\right]^{-} \quad(\mathrm{m} / \mathrm{z}$ calc 1348.9945 ; found 1348.9923) and $\left[\mathrm{Fe}_{2}(\mathrm{HPBA})(\mathrm{HCOO})(\mathrm{O})_{2}\left(\mathrm{ClO}_{4}\right)_{2}\right]^{-}$( $\mathrm{m} / z$ calc 1334.9789; found 1334.9774). After standing for 2 weeks in acetonitrile, the low resolution mass spectrum displays a peak at $\mathrm{m} / \mathrm{z} 642$ consistent with formation of the dimer, $\left[\mathrm{Fe}_{2}(\mathrm{HPBA})(\mathrm{OAc})(\mathrm{OH})\left(\mathrm{OH}_{2}\right)_{2}\right]^{+}$in solution, although we have been unable to isolate this complex.

\section{Visible absorption and magnetic circular dichroism spectra}

The UV-vis absorption spectrum of $\left[\mathrm{Fe}_{4}(\mathrm{HPBA})_{2}(\mathrm{OAc})_{2}(\mu-\mathrm{O})(\mu\right.$ $\left.\mathrm{OH})\left(\mathrm{OH}_{2}\right)_{2}\right] \mathrm{ClO}_{4} \cdot 5 \mathrm{H}_{2} \mathrm{O}$ in acetonitrile exhibits bands at 481 and $313 \mathrm{~nm}\left(\varepsilon=6050\right.$ and $14650 \mathrm{M}^{-1} \mathrm{~cm}^{-1}$, respectively) assigned as charge transfer transitions between the ligand and the iron(III) centres. The spectra for similar diiron(III) complexes display a broad absorption band at $601 \mathrm{~nm}\left(\varepsilon \sim 7700 \mathrm{M}^{-1} \mathrm{~cm}^{-1}\right)$ and $568 \mathrm{~nm}\left(\varepsilon \sim 4760 \mathrm{M}^{-1} \mathrm{~cm}^{-1}\right),{ }^{34}$ whilst $\mathrm{Fe}(\mathrm{III}) \mathrm{Fe}(\mathrm{II})$ analogues display maxima at $540 \mathrm{~nm}\left(\varepsilon \sim 4840 \mathrm{M}^{-1} \mathrm{~cm}^{-1}\right), 516 \mathrm{~nm}$ $\left(\varepsilon \sim 4560 \mathrm{M}^{-1} \mathrm{~cm}^{-1}\right)$, and $554 \mathrm{~nm}\left(\varepsilon \sim 950 \mathrm{M}^{-1} \mathrm{~cm}^{-1}\right),{ }^{34,35}$ assigned as phenolate to iron(III/II) charge transfer transitions. The intermolecular $\mu$-oxide bond in $\left[\mathrm{Fe}_{4}(\mathrm{HPBA})_{2}(\mathrm{OAc})_{2}(\mu-\mathrm{O})(\mu\right.$ $\left.\mathrm{OH})\left(\mathrm{OH}_{2}\right)_{2}\right]^{+}$and similar diiron(III) complexes is believed to cause a blue shift in 400-500 $\mathrm{nm}$ absorption bands arising from increased $\pi$ bonding between the iron(III) and $\mu$-oxo atoms with increase in the $\mathrm{Fe}-\mathrm{O}-\mathrm{Fe}$ angle. ${ }^{36,37}$

The MCD spectrum of $\left[\mathrm{Fe}_{4}(\mathrm{HPBA})_{2}(\mathrm{OAc})_{2}(\mu-\mathrm{O})(\mu-\mathrm{OH})-\right.$ $\left.\left(\mathrm{OH}_{2}\right)_{2}\right] \mathrm{ClO}_{4} \cdot 5 \mathrm{H}_{2} \mathrm{O}$ displays only a weak signal at very low temperatures $(1.8 \mathrm{~K})$ indicative of an $S=0$ ground state. The signal increased slightly with temperature before decreasing at $50 \mathrm{~K}$ indicating $\mathrm{C}$ term behaviour with an excited state $>25 \mathrm{~cm}^{-1}$.

\section{Magnetic susceptibility}

The $\chi_{\mathrm{M}} T$ product at $300 \mathrm{~K}$ is $4.49 \mathrm{~cm}^{3} \mathrm{~mol}^{-1} \mathrm{~K}$, significantly below the value theoretically predicted for four isolated $S=5 / 2$ spins $\left(17.51 \mathrm{~cm}^{3} \mathrm{~mol}^{-1} \mathrm{~K}, g=2.0\right)$, thus indicating dominant antiferromagnetic interactions. This is also corroborated by the constant drop of the $\chi_{\mathrm{M}} T$ product upon cooling, down to a value of $0.059 \mathrm{~cm}^{3} \mathrm{~mol}^{-1} \mathrm{~K}$ at $2 \mathrm{~K}$ and by the drop of the magnetic susceptibility $\chi_{\mathrm{M}}$ upon cooling $\left(0.010 \mathrm{~cm}^{3} \mathrm{~mol}^{-1}\right.$ at $\left.16 \mathrm{~K}\right)$ (Fig. 5). An increase of magnetic susceptibility below $16 \mathrm{~K}$ is attributed to ferric paramagnetic impurities, which, however, do not seem to exhibit a strict Curie behaviour, as evidenced by the lack of a clear plateau in the low-temperature region of the $\chi_{\mathrm{M}} T v s . T$ plot.

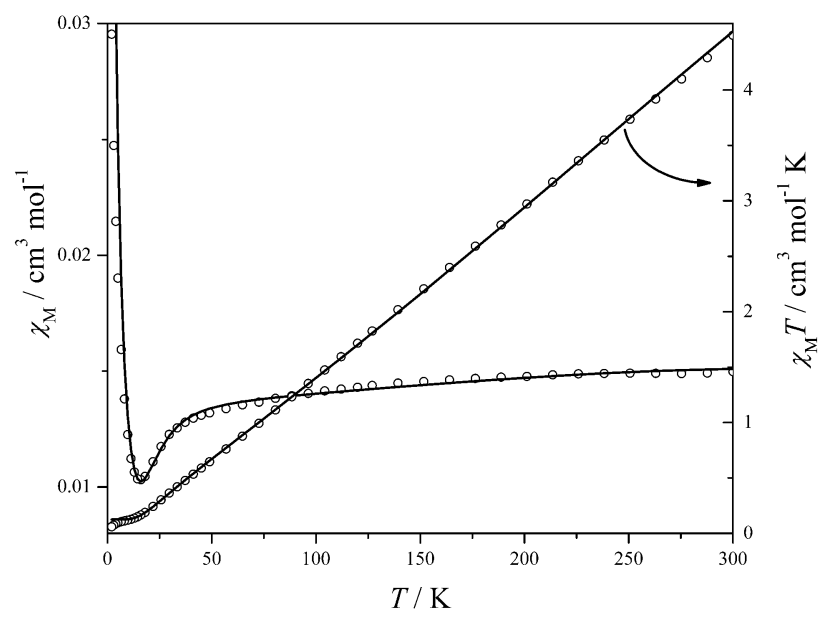

Fig. $5 \chi_{\mathrm{M}}$ and $\chi_{\mathrm{M}} T$ vs. $T$ experimental data points and calculated curves for $\left[\mathrm{Fe}_{4}(\mathrm{HPBA})_{2}(\mu-\mathrm{O})(\mu-\mathrm{OH})(\mathrm{OAc})_{2}\left(\mathrm{OH}_{2}\right)_{2}\right] \mathrm{ClO}_{4} \cdot 5 \mathrm{H}_{2} \mathrm{O}$ according to the model of eqn (1).

Examination of the crystal structure of $\left[\mathrm{Fe}_{4}(\mathrm{HPBA})_{2}(\mathrm{OAc})_{2}(\mu-\right.$ $\left.\mathrm{O})(\mu-\mathrm{OH})\left(\mathrm{OH}_{2}\right)_{2}\right] \mathrm{ClO}_{4} \cdot 5 \mathrm{H}_{2} \mathrm{O}$ indicates that due to the lack of symmetry, four exchange interactions would be rigorously required for the interpretation of its magnetic properties. However, its dimer-of-dimers structure allows for a simplification of the model, considering a common intradimer interaction $\left(J_{12}=J_{34}=J_{1}\right)$ (Fig. 6). As far as the interdimer interactions $\left(J_{23}=J_{3}\right.$ and $J_{14}=$ $J_{2}$ ) are concerned, these could not be a priori considered equal, due to the proton localization on one of the bridging oxides, and the subsequent asymmetry of the interdimer bridges $[\mathrm{Fe}(1)-\mathrm{O}(16)-$ $\left.\mathrm{Fe}(4)=146.81(21)^{\circ}, \mathrm{Fe}(2)-\mathrm{O}(8)-\mathrm{Fe}(3)=144.00(22)^{\circ}\right]$. Thus, to test whether these are indeed equal, initial fitting attempts considering $J_{2}=J_{3}$ were carried out. These yielded poor results, and it was thus decided to lift this constraint, and consider that $J_{2} \neq J_{3}$. The Hamiltonian used was therefore:

$$
\hat{H}=-2\left[J_{1}\left(\hat{S}_{1} \hat{S}_{2}+\hat{S}_{3} \hat{S}_{4}\right)+J_{3} \hat{S}_{2} \hat{S}_{3}+J_{2} \hat{S}_{4} \hat{S}_{1}\right]
$$

Due to the relatively large contribution of the paramagnetic impurities, the fits were sensitive to the temperature range of the dataset to be fitted. The low-temperature data (below $10 \mathrm{~K}$ ) could not be satisfactorily fitted, probably due to the non-Curie behaviour of the paramagnetic impurities, so these were omitted 




Fig. 6 Spin-coupling scheme for $\left[\mathrm{Fe}_{4}(\mathrm{HPBA})_{2}(\mu-\mathrm{O})(\mu-\mathrm{OH})(\mathrm{OAc})_{2}\right.$ $\left.\left(\mathrm{OH}_{2}\right)_{2}\right] \mathrm{ClO}_{4} \cdot 5 \mathrm{H}_{2} \mathrm{O}$.

from the datasets. Satisfactory fits could be obtained above $10 \mathrm{~K}$, with noticeable improvements resulting from omission of the low temperature $(<10 \mathrm{~K})$ data points. A satisfactory compromise was achieved by considering the data between 11 and $300 \mathrm{~K}$. Bestfit parameters were $J_{1}=-28.8 \mathrm{~cm}^{-1}, J_{2}=-39.9 \mathrm{~cm}^{-1}, J_{3}=$ $-13.2 \mathrm{~cm}^{-1}, g=2.0$ (fixed), $\rho=0.44 \%$ with $R=8.6 \times 10^{-5}$ (Fig. 5), leading to an $S=0$ ground state, well separated from the first excited $S=1$ state, at $47.5 \mathrm{~cm}^{-1}$. These values are consistent with exchange couplings between high-spin ferric $(S=5 / 2)$ ions bridged by monatomic oxygen bridges. ${ }^{36}$

Bridging between each $\mathrm{Fe}-\mathrm{Fe}$ pair in $\left[\mathrm{Fe}_{4}(\mathrm{HPBA})_{2}(\mathrm{OAc})_{2}(\mu-\right.$ $\left.\mathrm{O})(\mu-\mathrm{OH})\left(\mathrm{OH}_{2}\right)_{2}\right] \mathrm{ClO}_{4} \cdot 5 \mathrm{H}_{2} \mathrm{O}$ is mediated by one monatomic bridge $\left(\mathrm{O}^{2-}, \mathrm{OR}^{-}, \mathrm{OH}^{-}\right)$, unsupported by auxiliary bridges. So ideally, the derived couplings should be comparable to respective couplings within singly-bridged diferric complexes with similar unsupported monatomic bridges. However, although such examples are abundant for oxo-bridged diferric complexes, cases of phenoxo- or hydroxo-bridged complexes are rare. Unsupported oxo-bridged, high-spin diferric complexes display a spread of their exchange couplings, ${ }^{2}$ which range from -42 to $-195 \mathrm{~cm}^{-1} . J_{2}$ is at the low limit of this range. It is probable that hydrogen bonding with the proton of the adjacent hydroxide confers a partial hydroxo character to the bridge, which thus mediates a weaker coupling. $J_{1}$ on the other hand is significantly stronger than the exchange couplings encountered in $\mathrm{Fe}^{\mathrm{III}}-\left(\mu-\mathrm{OPh}^{-}\right)_{2}-\mathrm{Fe}^{\mathrm{III}}$ diiron complexes $\left(+1.2\right.$ to $\left.-8.9 \mathrm{~cm}^{-1}\right) .{ }^{38}$ It should be noted however, that in the case of $\left[\mathrm{Fe}_{4}(\mathrm{HPBA})_{2}(\mathrm{OAc})_{2}(\mu-\mathrm{O})(\mu-\mathrm{OH})\left(\mathrm{OH}_{2}\right)_{2}\right]^{+}$only one phenoxo bridge is present, and that the $\mathrm{Fe}-\mathrm{O}-\mathrm{Fe}$ angle is much larger $\left(\sim 121^{\circ}\right)$ than that observed in the previous examples $(97.1-$ $110^{\circ}$ ). Finally, $J_{3}$ is comparable to the values encountered for dihydroxo-bridged diferric complexes $\left(-5.5\right.$ to $\left.-11.7 \mathrm{~cm}^{-}\right)$and within the range determined for singly hydroxo-bridged $\mathrm{Fe}^{\mathrm{III}}-\mathrm{Fe}^{\mathrm{III}}$ interactions $\left(-10.7\right.$ to $\left.-21 \mathrm{~cm}^{-1}\right) .^{15,39,40}$

To verify the uniqueness of this solution an error-level plot (Fig. 7) was drawn for various combinations of $J_{2}$ and $J_{3}$ values. This verified our solution as unique, by showing two equivalent minima. The shape of the contour plots around the minima was indicative of the uncertainties of $J_{2}$ and $J_{3}$; while the weaker coupling is fairly well determined, the stronger one is less so. However, the quality of the fits and the agreement of the present values with those previously determined, support the validity of our solution.

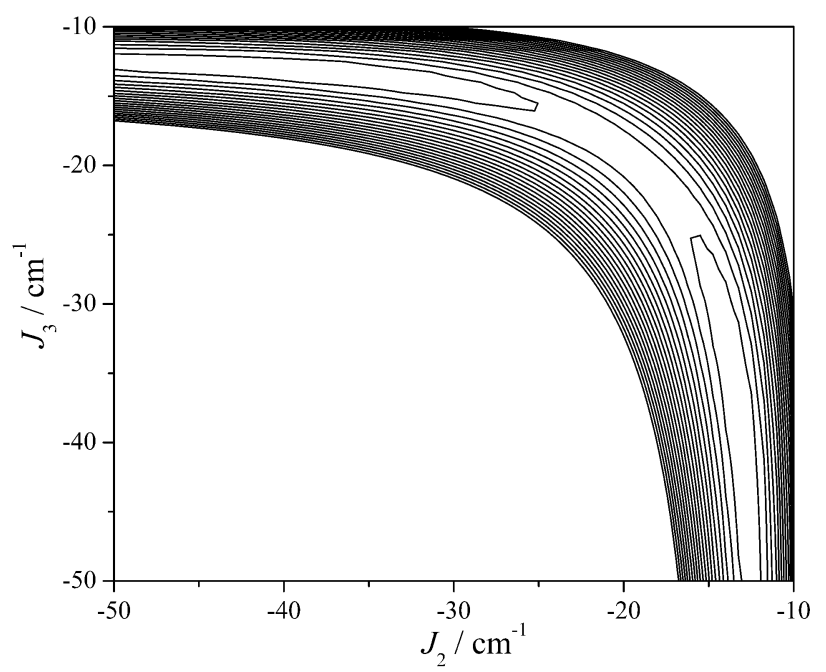

Fig. 7 Error contour plot for various $J_{2}$ vs. $J_{3}$ combinations for $\left[\mathrm{Fe}_{4}(\mathrm{HHPBA})_{2}(\mu-\mathrm{O})(\mu-\mathrm{OH})(\mathrm{OAc})_{2}\left(\mathrm{OH}_{2}\right)_{2}\right] \mathrm{ClO}_{4} \cdot 5 \mathrm{H}_{2} \mathrm{O}$. The two minima are interchangeable due to the symmetry of the problem.

\section{Mössbauer spectroscopy}

Mössbauer spectra of $\left[\mathrm{Fe}_{4}(\mathrm{HPBA})_{2}(\mathrm{OAc})_{2}(\mu-\mathrm{O})(\mu-\mathrm{OH})\left(\mathrm{OH}_{2}\right)_{2}\right]-$ $\mathrm{ClO}_{4} \cdot 5 \mathrm{H}_{2} \mathrm{O}$ are shown in Fig. 8. These exhibit composite quadrupole-split doublets with parameters typical of high-spin ferric ions in octahedral environments (Table 3). An increase in the isomer shifts upon cooling is attributed to a second-order Doppler effect. ${ }^{41}$ The complex contains two different ferric sites with $\mathrm{NO}_{5}(\mathrm{Fe}(1) / \mathrm{Fe}(3))$ and $\mathrm{N}_{2} \mathrm{O}_{4}(\mathrm{Fe}(2) / \mathrm{Fe}(4))$ donor-atom sets. However, based on the crystal structure of $\left[\mathrm{Fe}_{4}(\mathrm{HPBA})_{2}(\mathrm{OAc})_{2}(\mu-\right.$ $\left.\mathrm{O})(\mu-\mathrm{OH})\left(\mathrm{OH}_{2}\right)_{2}\right] \mathrm{ClO}_{4} \cdot 5 \mathrm{H}_{2} \mathrm{O}$ (at $\left.89 \mathrm{~K}\right)$ these coordination spheres are not identical, since $\mathrm{O}(8)$ is a hydroxo- and $\mathrm{O}(16)$ an oxo-bridge. Therefore, there are two types of $\mathrm{NO}_{5}$ and $\mathrm{N}_{2} \mathrm{O}_{4}$

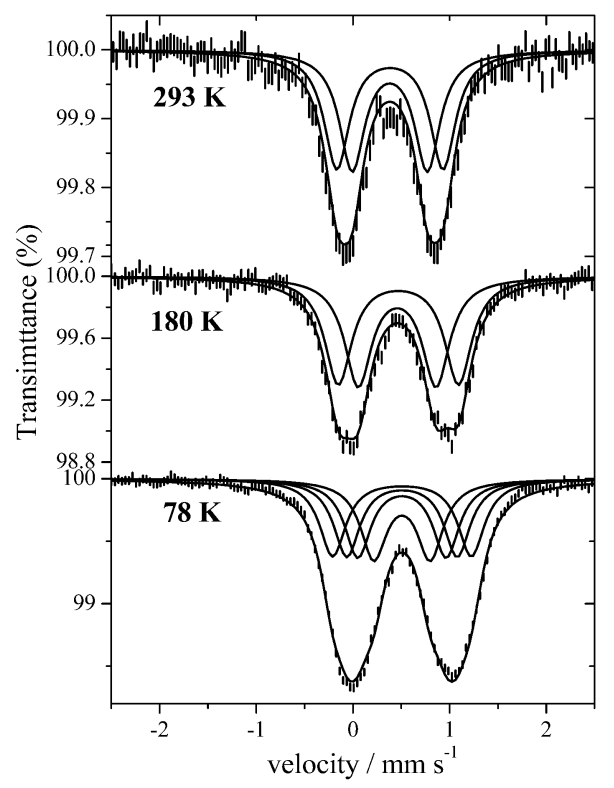

Fig. 8 Mössbauer spectra of $\left[\mathrm{Fe}_{4}(\mathrm{HPBA})_{2}(\mathrm{OAc})_{2}(\mu-\mathrm{O})(\mu-\mathrm{OH})\left(\mathrm{OH}_{2}\right)_{2}\right]-$ $\mathrm{ClO}_{4} \cdot 5 \mathrm{H}_{2} \mathrm{O}$ at various temperatures. The spectra are fitted to the models described in the text. 
Table 3 Mössbauer parameters for $\left[\mathrm{Fe}_{4}(\mathrm{HPBA})_{2}(\mathrm{OAc})_{2}(\mu-\mathrm{O})(\mu-\right.$ $\left.\mathrm{OH})\left(\mathrm{OH}_{2}\right)_{2}\right] \mathrm{ClO}_{4} \cdot 5 \mathrm{H}_{2} \mathrm{O}$

\begin{tabular}{llllll}
\hline Site & $T / \mathrm{K}$ & $\delta / \mathrm{mm} \mathrm{s}^{-1}$ & $\Delta E_{\mathrm{Q}} / \mathrm{mm} \mathrm{s}^{-1}$ & $(\Gamma / 2) / \mathrm{mm} \mathrm{s}^{-1}$ & Ratio \\
\hline A & 293 & $0.38(1)$ & $1.10(1)$ & $0.16(1)$ & 50 \\
B & & $0.38(1)$ & $0.78(1)$ & $0.16(1)$ & 50 \\
A & 180 & $0.47(1)$ & $1.24(1)$ & $0.17(1)$ & 50 \\
B & & $0.46(1)$ & $0.81(1)$ & $0.17(1)$ & 50 \\
A1 & 78 & $0.51(1)$ & $1.43(1)$ & $0.16(1)$ & 25 \\
A2 & & $0.51(1)$ & $1.14(1)$ & $0.16(1)$ & 25 \\
B1 & & $0.51(1)$ & $0.91(1)$ & $0.16(1)$ & 25 \\
B2 & & $0.51(1)$ & $0.58(1)$ & $0.16(1)$ & 25 \\
\hline
\end{tabular}

coordination spheres $\left(\mathrm{NO}_{5}{ }^{\text {oxo }} / \mathrm{NO}_{5}\right.$ hydroxo and $\mathrm{N}_{2} \mathrm{O}_{4}{ }^{\text {oxo }} / \mathrm{N}_{2} \mathrm{O}_{4}$ hydroxo respectively) and the data may in principle be analysed assuming four quadrupole-split doublets in a $1: 1: 1: 1$ ratio. Due to the similarities of the donor atom sets $\left(\mathrm{NO}_{5}\right.$ and $\left.\mathrm{N}_{2} \mathrm{O}_{4}\right)$ with only nitrogen and oxygen atoms, we consider these doublets as nested (i.e. of similar isomer shifts and different quadrupole splittings). In any case, however, site assignment will be ambiguous, due to the low sensitivity of HS-Fe(III) Mössbauer parameters to the coordination environment, and the similarities of the coordination spheres of the four sites.

Initial examination of the spectra reveals that linewidths decrease upon heating. Thus, the $78 \mathrm{~K}$ spectrum could only be fitted to the above mentioned model of four doublets, while higher-temperature spectra exhibited narrowing of the linewidths, allowing a simpler model for their interpretation. The 180 and $293 \mathrm{~K}$ spectra could be simulated by a pair of quadrupole-split doublets in a 1:1 ratio and reasonable linewidths. Although reliable assignments are difficult, as discussed above, for purposes of comparison, indicative fitting parameters are shown in Table 3.

This temperature-dependent behaviour suggests the influence of dynamic effects on the Mössbauer spectra. In particular, we could assume that upon heating, the proton trapped between oxides $\mathrm{O}(8)$ and $\mathrm{O}(16)$ may start "hopping" between the two. This effect, if thermally accelerated to a sufficient degree, could surpass the Mössbauer timescale and lead to thermally averaged spectra of the two different conformations. This has been observed in another $\mathrm{Fe}_{4}$ cluster exhibiting a $[\mathrm{OHO}]^{3-}$ bridge. ${ }^{15}$ In that case, however, there was only one coordination sphere $\left(\mathrm{N}_{2} \mathrm{O}_{4}\right)$, which, when split to two $\left(\mathrm{N}_{2} \mathrm{O}_{4}{ }^{\text {oxo }} / \mathrm{N}_{2} \mathrm{O}_{4}{ }^{\text {hydroxo }}\right)$, yielded two wellresolved doublets. In our case, the two coordination spheres split to four, leading to more overlapped spectra that are harder to analyse.

\section{Conclusion}

The complex $\left.\left[\mathrm{Fe}_{4}(\mathrm{HPBA})_{2}\right)(\mu-\mathrm{O})(\mu-\mathrm{OH})(\mathrm{OAc})_{2}\left(\mathrm{OH}_{2}\right)_{2}\right] \mathrm{ClO}_{4}$. $5 \mathrm{H}_{2} \mathrm{O}$ has been prepared from a new binucleating ligand. The intricate $\mu$-phenoxo, $\mu$-oxo, $\mu$-hydroxo and $\mu$-O-H-O dimer of dimer structure has been characterised by X-ray crystallography, Mössbauer spectroscopy and magnetochemical studies involving consideration of the inter- and intra-dimer interactions. Structurally, the asymmetric binuclear units have similarities with the active site of uteroferrin although lacking the subtlety of the metallobiosite's ability to maintain a heterovalent environment. ${ }^{17}$ The model does reproduce the putative terminal hydroxide/aqua ligand of the trivalent iron site in uteroferrin, although these moieties do act as bridging agents for the formation of the tetramer. The synthetic strategy employed offers the possibility for further elaboration introducing chiral centres by replacing glycine, and exploring the synthesis of mixed metal systems.

\section{Experimental}

\section{Chemicals}

All reagents and solvents were obtained commercially and were used without further purification.

\section{Instrumental methods}

NMR spectra were measured using Bruker AV300 (300 MHz) and AV500 (500 MHz) instruments. Spectra were recorded in $\mathrm{CDCl}_{3}$, with chemical shifts reported in parts per million calibrated using the resonances for $\mathrm{CDCl}_{3}, \delta_{\mathrm{H}}\left(\mathrm{CHCl}_{3}\right)=7.24 \mathrm{ppm}$ and $\delta_{\mathrm{C}}\left(\mathrm{CDCl}_{3}\right)=77.0 \mathrm{ppm}$. Low and high resolution positive-ion mass spectra were obtained using a Finnigan MAT 900 XL mass spectrometer and methanol solutions for the ligand, and acetonitrile for the metal complex. All samples were subjected to electrospray ionization, with voltages tuned to optimize the signals. Elemental analyses were performed using the microanalysis facilities at The University of Queensland and The University of Otago. UV-vis spectra were measured in acetonitrile with a Hitachi U-3000 spectrometer (10 mm quartz cells) over the 200 $800 \mathrm{~nm}$ region and with a Cary17 spectrometer $(1 \mathrm{~mm}$ quartz cells) over the 200-2500 $\mathrm{nm}$ region at ambient temperature. MCD spectra of a $0.74 \mathrm{mM}$ solution of $\left[\mathrm{Fe}_{4}(\mathrm{HPBA})_{2}\right)(\mu-\mathrm{O})(\mu-$ $\left.\mathrm{OH})(\mathrm{OAc})_{2}\left(\mathrm{OH}_{2}\right)_{2}\right] \mathrm{ClO}_{4} \cdot 5 \mathrm{H}_{2} \mathrm{O}$ in ethanol-methanol $(50: 50)$ were measured at $\pm 7 \mathrm{~T}$ using a R669 PMT detector, calcite polarizer, and $24 \mathrm{~V} / 250 \mathrm{~W}$ halogen lamp over multiple temperatures. Variable-temperature (78-293 K) Mössbauer spectra were collected at the Laboratory of Mössbauer Spectroscopy of the Institute of Materials Science of NCSR "Demokritos" with a constant acceleration spectrometer using a ${ }^{57} \mathrm{Co}(\mathrm{Rh})$ source and a variable temperature Oxford cryostat. Home-written routines were used to fit the Mössbauer parameters and determine their standard deviations of statistical origin (given in parentheses). Isomer shift values $(\delta)$ are reported relative to iron foil at $300 \mathrm{~K}$. Magnetic susceptibility measurements $(2-300 \mathrm{~K})$ were made using a Quantum Design MPMS SQUID magnetometer with an applied field of $0.1 \mathrm{~T}$. The crystalline sample of $\left[\mathrm{Fe}_{4}(\mathrm{HPBA})_{2}\right)(\mu-$ $\left.\mathrm{O})(\mu-\mathrm{OH})(\mathrm{OAc})_{2}\left(\mathrm{OH}_{2}\right)_{2}\right] \mathrm{ClO}_{4} \cdot 5 \mathrm{H}_{2} \mathrm{O}$ was enclosed in a calibrated gelatine capsule positioned in the centre of a drinking straw fixed to the end of the sample rod. Data were corrected with the standard procedure for the contribution of the sample holder and diamagnetism of the sample. The magnetic susceptibility has been computed by exact calculation of the energy levels associated with the spin Hamiltonian, through diagonalization of the full matrix with a general-symmetry program. ${ }^{42,43}$ Leastsquares fittings were accomplished with an adapted version of the function-minimization program MINUIT. ${ }^{44}$ The error factor $R$ is defined as $R=\sum \frac{\left(x_{\exp }-x_{\text {calc }}\right)^{2}}{N x_{\mathrm{exp}}^{2}}$, where $N$ is the number of experimental points. 


\section{Crystallographic measurements}

X-Ray diffraction data for a crystal of $\left[\mathrm{Fe}_{4}(\mathrm{HPBA})_{2}\right)(\mu-\mathrm{O})(\mu-$ $\left.\mathrm{OH})(\mathrm{OAc})_{2}\left(\mathrm{OH}_{2}\right)_{2}\right] \mathrm{ClO}_{4} \cdot 5 \mathrm{H}_{2} \mathrm{O}$ were collected with a Bruker Apex II diffractometer with graphite monochromated Mo-K $\alpha(\lambda=$ $0.71073 \AA$ ) radiation. The structure was solved by direct methods using SIR $97^{45}$ and refined on $F^{2}$ using SHELXL97 ${ }^{46}$ running within the WinGX interface. ${ }^{47}$ Plots were drawn using ORTEP3. ${ }^{48}$ The hydrogen positions for the amine, methylene and coordinated water molecules were calculated and included in the final refinement cycle. The hydrogen atoms of the water molecules of crystallization were not located. All non-hydrogen atoms were refined with anisotropic thermal parameters. Selected crystal data and some details of refinements are given in Table 1. Selected bond distances and angles are presented in Table 2.

\section{Syntheses of the ligand and metal complex}

2-Hydroxy-3-hydroxymethyl-5-methylbenzaldehyde and 2-hydroxy-3-chloromethyl-5-methylbenzaldehyde were prepared following a previously described method. ${ }^{49}$

$\boldsymbol{N}$-(2-Hydroxybenzyl)glycine ethyl ester. The preparation of this compound was adapted from the method described by Koh. ${ }^{50}$ Glycine ethyl ester hydrochloride ( $4.17 \mathrm{~g}, 29.9 \mathrm{mmol})$ was dissolved in aqueous potassium hydroxide $\left(30 \mathrm{~cm}^{3}, 1 \mathrm{M}\right)$. A solution of salicylaldehyde (3.66 g, $30 \mathrm{mmol})$ in ethanol $\left(30 \mathrm{~cm}^{3}\right)$ was added dropwise and the resulting yellow solution was stirred for $15 \mathrm{~min}$. Methanol $\left(30 \mathrm{~cm}^{3}\right)$ was added dropwise and the solution became a clear yellow. The solution was stirred at room temperature for another $2 \mathrm{~h}$ and then transferred to an ice bath for $10 \mathrm{~min}$. Sodium borohydride ( $2 \mathrm{~g}, 0.053 \mathrm{~mol}$ ) was added in portions whilst the solution remained in ice. The solution bleached and hydrogen gas was evolved. The solution was stirred at room temperature for a further $15 \mathrm{~min}$, after which time the $\mathrm{pH}$ was adjusted to about 4 using glacial acetic acid. Further sodium borohydride was added until the yellow solution bleached, and the solvent was removed. Water $\left(75 \mathrm{~cm}^{3}\right)$ was added to the flask to give a white precipitate and the mixture was extracted with dichloromethane $\left(3 \times 50 \mathrm{~cm}^{3}\right)$. The combined organic layers were washed with a saturated sodium hydrogen carbonate solution $\left(3 \times 30 \mathrm{~cm}^{3}\right)$, dried over anhydrous sodium sulfate, filtered and the solvent removed to leave a pale yellow oil that crystallised in the refrigerator (yellow crystals, $2.23 \mathrm{~g}, 36 \%$ yield). $\mathrm{H} \mathrm{NMR}\left(\delta_{\mathrm{H}}, \mathrm{CDCl}_{3}\right): 1.28(\mathrm{t}, 3 \mathrm{H}), 3.40$ (s, 2H), 3.96 (s, 2H), $4.22(\mathrm{q}, 2 \mathrm{H}), 6.82(\mathrm{t}, 1 \mathrm{H}), 6.84(\mathrm{~d}, 1 \mathrm{H}), 6.97$ $(\mathrm{d}, 1 \mathrm{H}), 7.18(\mathrm{t}, 1 \mathrm{H}) .{ }^{13} \mathrm{C} \mathrm{NMR}\left(\delta_{\mathrm{C}}, \mathrm{CDCl}_{3}\right): 14.05,48.77,51.87$, $61.11,116.36,119.16,121.78,128.64,128.93,157.71,171.26$.

[(3-Formyl-2-hydroxy-5-methyl-benzyl)-(2-hydroxy-benzyl)amino]acetic acid ethyl ester. $\quad N$-(2-Hydroxybenzyl)glycine ethyl ester $(2.16 \mathrm{~g}, 10.32 \mathrm{mmol})$ was dissolved in tetrahydrofuran $\left(100 \mathrm{~cm}^{3}\right)$ and 2-hydroxy-3-chloromethyl-5-methylbenzaldehyde $(2.19 \mathrm{~g}, 13.18 \mathrm{mmol})$ was added with stirring to the bright yellow solution which turned a duller yellow. Triethylamine $\left(5.5 \mathrm{~cm}^{3}\right.$, $39.57 \mathrm{mmol}$ ) was added dropwise and the solution changed from clear to opaque with some pale yellow precipitate forming. The mixture was left stirring overnight, gravity filtered and the solvent removed to leave a yellow oil. Water $\left(35 \mathrm{~cm}^{3}\right)$ was added to the oil to give a yellow precipitate. The mixture was extracted using dichloromethane $\left(3 \times 35 \mathrm{~cm}^{3}\right)$, the combined organic layers dried over anhydrous sodium sulfate, filtered and the solvent removed to give the product as an orange oil $(3.24 \mathrm{~g}, 92 \%$ yield $)$. H NMR $\left(\delta_{\mathrm{H}}\right.$, $\left.\mathrm{CDCl}_{3}\right): 1.27(\mathrm{t}, 3 \mathrm{H}), 2.30(\mathrm{~s}, 3 \mathrm{H}), 3.31(\mathrm{~s}, 2 \mathrm{H}), 3.83(\mathrm{~s}, 2 \mathrm{H}), 3.92(\mathrm{~s}$, $2 \mathrm{H}), 4.19(\mathrm{q}, 2 \mathrm{H}), 7.31(\mathrm{t}$ and $\mathrm{d}, 6 \mathrm{H}), 9.82(\mathrm{~s}, 1 \mathrm{H}) .{ }^{13} \mathrm{C} \mathrm{NMR}\left(\delta_{\mathrm{C}}\right.$, $\mathrm{CDCl}_{3}$ ): 14.12, 20.23, 50.76, 53.28, 57.29, 60.86, 116.32, 119.19, $120.31,121.64,124.83,129.07,129.10,129.23,133.32,139.70$, $157.56,158.11,170.68,196.43$.

Methyl 2-((2-hydroxy-5-methyl-3-((pyridin-2-ylmethylamino)methyl)benzyl)(2-hydroxybenzyl)amino)acetate, H$_{2}$ HPBMA. [(3-Formyl-2-hydroxy-5-methyl-benzyl)-(2-hydroxy-benzyl)-amino]acetic acid ethyl ester $(5.35 \mathrm{~g}, 0.016 \mathrm{~mol})$ was dissolved in methanol $\left(500 \mathrm{~cm}^{3}\right)$. A solution of 2-aminomethylpyridine $(1.64 \mathrm{~g}, 0.0152 \mathrm{~mol})$ in methanol $\left(150 \mathrm{~cm}^{3}\right)$ was added dropwise with stirring. The opaque, bright yellow solution was stirred at $50{ }^{\circ} \mathrm{C}$ for $2 \mathrm{~h}$ during which time it became clear. Sodium borohydride ( $2 \mathrm{~g}, 0.053 \mathrm{~mol}$ ) was added in portions with stirring, the solution heated to reflux for $2 \mathrm{~h}$ and then cooled to room temperature overnight. The solvent was then removed to leave a bright orange/red solid. Water $\left(100 \mathrm{~cm}^{3}\right)$ and dichloromethane $\left(100 \mathrm{~cm}^{3}\right)$ were added, and the $\mathrm{pH}$ of the aqueous layer adjusted to about 4 using concentrated hydrochloric acid. The aqueous layer was extracted using dichloromethane $\left(2 \times 100 \mathrm{~cm}^{3}\right)$, dried over anhydrous sodium sulfate, filtered and the solvent removed to leave a yellow/orange solid (3.14 g, 48\%). The crude product was purified by column chromatography on silica, loading onto the column with chloroform and eluting with a chloroform-methanol mixture $(95: 5)$. The solvent was removed to give the product as an orange-yellow oil ( $0.7 \mathrm{~g}, 11 \%$ yield). Found: C, 66.38; H, 6.40; $\mathrm{N}, 8.59 \%$. Calc. for $\mathrm{C}_{25} \mathrm{H}_{29} \mathrm{~N}_{3} \mathrm{O}_{4} \cdot \mathrm{CH}_{3} \mathrm{OH}: \mathrm{C}, 66.77 ; \mathrm{H}, 7.11 ; \mathrm{N}$, 8.99\%. LRMS $\left(\mathrm{CH}_{3} \mathrm{OH}\right): \mathrm{m} / z$ (assigned ion) $436\left(\left[\mathrm{M}+\mathrm{H}^{+}\right]^{+}\right.$, calculated for $\left[\mathrm{C}_{25} \mathrm{H}_{30} \mathrm{~N}_{3} \mathrm{O}_{4}\right]^{+} 436,458\left(\left[\mathrm{M}+\mathrm{Na}^{+}\right]^{+}\right.$, calculated for $\left[\mathrm{C}_{25} \mathrm{H}_{28} \mathrm{~N}_{3} \mathrm{O}_{4} \mathrm{Na}\right]^{+} 458$ ). HRMS $\left(\mathrm{CH}_{3} \mathrm{OH}\right): \mathrm{m} / z$ (assigned ion) 436.2251 $\left(\left[\mathrm{M}+\mathrm{H}^{+}\right]^{+}\right.$, calculated for $\left[\mathrm{C}_{25} \mathrm{H}_{30} \mathrm{~N}_{3} \mathrm{O}_{4}\right]^{+}$436.2236. $\mathrm{H}$ $\operatorname{NMR}\left(\delta_{\mathrm{H}}, \mathrm{CDCl}_{3}\right): 2.20(\mathrm{~s}, 3 \mathrm{H}), 3.34(\mathrm{~s}, 2 \mathrm{H}), 3.66(\mathrm{~s}, 3 \mathrm{H}), 3.83$ (s, 2H), 3.92 (s, 2H), 3.93 (s, 2H), 3.99 (s, 2H), 6.75 (t, 1H), 6.76 $(\mathrm{s}, 1 \mathrm{H}), 6.83(\mathrm{~d}, 1 \mathrm{H}), 6.91(\mathrm{~s}, 1 \mathrm{H}), 7.00(\mathrm{~d}, 1 \mathrm{H}), 7.16(\mathrm{t}, 1 \mathrm{H}), 7.22$ $(\mathrm{t}, 1 \mathrm{H}), 7.28(\mathrm{~d}, 1 \mathrm{H}), 7.66(\mathrm{t}, 1 \mathrm{H}), 8.57(\mathrm{~d}, 1 \mathrm{H}) .{ }^{13} \mathrm{C} \mathrm{NMR}\left(\delta_{\mathrm{C}}\right.$, $\left.\mathrm{CDCl}_{3}\right): 20.39,51.45,51.62,52.62,52.72,53.19,56.44,116.25$, $119.02,122.06,122.61,122.99,127.93,128.98,129.43,129.55$, $131.20,136.89,149.32,154.64,157.61,171.39$.

$\left[\mathrm{Fe}_{4}(\mathrm{HPBA})_{2}(\mathrm{OAc})_{2}(\mu-\mathrm{O})(\mu-\mathrm{OH})\left(\mathrm{OH}_{2}\right)_{2}\right] \mathrm{ClO}_{4} \cdot \mathbf{8} \mathrm{H}_{2} \mathrm{O}$. A methanol solution $\left(3 \mathrm{~cm}^{3}\right)$ of HHPBMA $(0.0477 \mathrm{~g}, 0.11 \mathrm{mmol})$ was added dropwise with stirring to a methanolic solution $\left(10 \mathrm{~cm}^{3}\right)$ of $\mathrm{FeCl}_{2} \cdot 4 \mathrm{H}_{2} \mathrm{O}(0.0414 \mathrm{~g}, 0.208 \mathrm{mmol})$ to give a dark purple solution. A methanol solution $\left(1 \mathrm{~cm}^{3}\right)$ of $\mathrm{CH}_{3} \mathrm{COONa}(0.0273 \mathrm{~g}$, $0.333 \mathrm{mmol}$ ) was immediately added dropwise to the solution and the solution then stirred at $40{ }^{\circ} \mathrm{C}$ for $15 \mathrm{~min}$. A methanol solution $\left(1 \mathrm{~cm}^{3}\right)$ of $\mathrm{NaClO}_{4}(0.0552 \mathrm{~g}, 0.451 \mathrm{mmol})$ was then added dropwise and stirring continued at $40{ }^{\circ} \mathrm{C}$ for $10-15 \mathrm{~min}$. Aqueous $\mathrm{KOH}$ (1 M, 5 drops) was added to the solution and stirring continued for a further $5 \mathrm{~min}$ at $40{ }^{\circ} \mathrm{C}$. The solution was then filtered and left to stand at room temperature to yield fine, cylindrical, purple crystals $(24.2 \mathrm{mg}, 4.05 \%$ yield $)$. Found: C, 41.76; $\mathrm{H}, 4.47 ; \mathrm{N}, 5.55 ; \mathrm{Cl}, 2.50 \%$. Calc. for $\mathrm{C}_{52} \mathrm{H}_{59} \mathrm{Fe}_{4} \mathrm{~N}_{6} \mathrm{O}_{20} \mathrm{Cl} \cdot 8 \mathrm{H}_{2} \mathrm{O}$ : $\mathrm{C}, 41.87 ; \mathrm{H}, 5.07 ; \mathrm{N}, 5.64 ; \mathrm{Cl}, 2.35 \%$. LRMS $\left(\mathrm{CH}_{3} \mathrm{CN}\right)$ : (assigned ion; $\left.m / z),\left(\left[\mathrm{Fe}_{4}(\mathrm{HPBA})_{2}\right)(\mu-\mathrm{O})(\mu-\mathrm{OH})(\mathrm{OAc})-\mathrm{H}^{+}\right]^{+} ; 1151\right)$, 
$\left.\left(\left[\mathrm{Fe}_{4}(\mathrm{HPBA})_{2}\right)(\mu-\mathrm{O})(\mu-\mathrm{OH})-2 \mathrm{H}^{+}\right]^{+} ; 1091\right),\left(\left[\mathrm{Fe}_{4}(\mathrm{HPBA})_{2}\right)(\mu-\mathrm{O})-\right.$ $\left.\left.\left.3 \mathrm{H}^{+}\right]^{+} ; \quad 1073\right), \quad\left[\mathrm{Fe}_{2}(\mathrm{HPBA})(\mathrm{OAc})(\mathrm{OH})\left(\mathrm{H}_{2} \mathrm{O}\right)_{2}\right]^{+} ; \quad 642\right)$. UV-vis $\left(\mathrm{CH}_{3} \mathrm{CN}\right), \lambda_{\max } / \mathrm{nm}\left(\varepsilon / \mathrm{M}^{-1} \mathrm{~cm}^{-1}\right): 481$ (6054), $313(\mathrm{sh})(14643)$, 277 (25248), 234 (sh) (38524), 217 (52066).

\section{Acknowledgements}

This work was funded by a grant from the Australian Research Council (DP0558652). We thank Dr Yiannis Sanakis for the acquisition of the Mössbauer spectra.

\section{References}

1 S. J. Lippard, Angew. Chem., Int. Ed. Engl., 1988, 27, 344.

2 J. D. M. Kurtz, Chem. Rev., 1990, 90, 585.

3 A. L. Feig and S. J. Lippard, Chem. Rev., 1994, 94, 759.

4 G. A. Clegg, J. E. Fitton, P. M. Harrison and A. Treffry, Prog. Biophys. Mol. Biol., 1980, 36, 53.

5 K. Wieghardt, Angew. Chem., Int. Ed. Engl., 1994, 33, 725.

6 V. L. Pecoraro, M. J. Baldwin and A. Gelasco, Chem. Rev., 1994, 94, 807.

7 V. K. Yachandra, V. J. DeRose, M. J. Latimer, I. Mukerji, K. Sauer and M. Klein, Science, 1993, 260, 675.

8 V. J. DeRose, I. Mukerji, M. J. Latimer, V. K. Yachandra, K. Sauer and M. P. Klein, J. Am. Chem. Soc., 1994, 116, 5239.

9 T. Tanase, T. Inagaki, Y. Yamada, M. Kato, E. Ota, M. Yamazaki, M. Sato, W. Mori, K. Yamaguchi, M. Mikuriya, M. Takahashi, M. Takeda, I. Kinoshita and S. Yano, J. Chem. Soc., Dalton Trans., 1998, 713.

10 N. Mitić, S. J. Smith, A. Neves, L. W. Guddat, L. R. Gahan and G Schenk, Chem. Rev, 2006, 106, 3338.

11 G. Schenk, Y. Ge, L. E. Carrington, C. J. Wynne, I. R. Searle, B. J. Carroll, S. E. Hamilton and J. de Jersey, Arch. Biochem. Biophys., 1999, 370, 183.

12 T. Klabunde and B. Krebs, Struct. Bonding (Berlin), 1997, 1, 177.

13 M. B. Twitchett and A. G. Sykes, Eur. J. Inorg. Chem., 1999, 2105.

14 N. Sträter, W. N. Lipscomb, T. Klabunde and B. Krebs, Angew. Chem., Int. Ed. Engl., 1996, 35, 2024.

15 A. K. Boudalis, N. Lalioti, G. A. Spyroulias, C. P. Raptopoulou, A. Terzis, A. Bousseksou, V. Tangoulis, J.-P. Tuchagues and S. P. Perlepes, Inorg. Chem., 2002, 41, 6474.

16 V. A. Grillo, G. R. Hanson, T. W. Hambley, L. R. Gahan, K. S. Murray and B. Moubaraki, J. Chem. Soc., Dalton Trans., 1997, 305.

17 L. W. Guddat, A. S. McAlpine, D. A. Hume, S. E. Hamilton, J. de Jersey and J. Martin, Structure, 1999, 7, 757.

18 Y. Lindqvist, E. Johansson, H. Kaija, P. Vihko and G. Schneider, J. Mol. Biol., 1999, 291, 135.

19 J. Uppenberg, F. Lindqvist, C. Svensson, B. Ek-Rylander and G. Andersson, J. Mol. Biol., 1999, 290, 201.

20 N. Sträter, T. Klabunde, P. Tucker, H. Witzel and B. Krebs, Science, $1995,268,1489$.

21 T. Klabunde, N. Sträter, R. Fröhlich, H. Witzel and B. Krebs, J. Mol. Biol., 1996, 259, 737.

22 S. K. Smoukov, L. Quaroni, X. Wang, P. E. Doan, B. M. Hoffman and L. Que, Jr., J. Am. Chem. Soc., 2002, 124, 2595.
23 D. L. Wang, R. C. Holz, S. S. David, L. Que, Jr. and M. T. Stankovich, Biochemistry, 1991, 30, 8187.

24 P. V. Bernhardt, G. Schenk and G. J. Wilson, Biochemistry, 2004, 43, 10387.

25 A. Neves, M. A. de Brito, V. Drago, K. Griesar and W. Haase, Inorg. Chim. Acta, 1995, 237, 131.

26 A. Horn, Jr., I. Vencato, A. J. Bortoluzzi, R. Hörner, R. A. Nome Silva, B. Spoganicz, V. Drago, H. Terenzi, M. C. B. de Oliveira, R. Werner, W. Haase and A. Neves, Inorg. Chim. Acta, 2005, 358, 339.

27 L. Westerheide, F. K. Müller, R. Than and B. Krebs, Inorg. Chem., 2001, 40, 1951

28 C. Duboc-Toia, S. Ménage, J.-M. Vincent, M. T. Averbuch-Pouchot and M. Fontecave, Inorg. Chem., 1997, 36, 6148.

29 C. E. McBeth, R. Gupta, K. R. Mitchell-Koch, V. G. Young, Jr., G. H. Lushington, W. H. Thompson, M. P. Hendrich and A. S. Borovik, J. Am. Chem. Soc., 2004, 126, 2556.

30 T. Tanase, C. Inoue, E. Ota, S. Yano, M. Takahashi and M. Takeda, Inorg. Chim. Acta, 2000, 297, 18.

31 R. T. Stibrany and S. M. Gorun, Angew. Chem., 1990, 102, 1195.

32 S. M. Gorun, R. T. Stibrany and A. Lillo, Inorg. Chem., 1998, 37, 836.

33 D. M. Prosperio, R. Hoffman and G. C. Dismukes, J. Am. Chem. Soc., 1992, 114, 4374

34 A. Neves, M. A. de Brito, I. Vencato, V. Drago, K. Griesar and W. Haase, Inorg. Chem., 1996, 35, 2360.

35 A. S. Borovik, V. Papaefthymiou, L. F. Taylor, O. P. Anderson and L. Que, Jr., J. Am. Chem. Soc., 1989, 111, 6183.

36 R. C. Holz, T. E. Elgren, L. L. Pearce, J. H. Zhang, C. J. O’Connor and L. Que, Jr., Inorg. Chem., 1993, 32, 5844.

37 R. C. Reem, J. M. McCormick, D. E. Richardson, F. J. Devlin, P. J. Stephens, R. L. Musselman and E. I. Solomon, J. Am. Chem. Soc., 1989, 111, 4688.

38 R. Werner, S. Ostrovsky, K. Griesar and W. Haase, Inorg. Chim. Acta, 2001, 326, 78.

39 S. Drüeke, K. Wieghardt, B. Nuber, J. Weiss, E. L. Bominaar, A. Saaryn, H. Winkler and A. X. Trautwein, Inorg. Chem., 1989, 28, 4477.

40 J. Jullien, G. Juhász, E. Dumas, C. R. Mayer, J. Marrot, E. Rivière, E. L. Bominaar, E. Münck and F. Sécheresse, Inorg. Chem., 2006, 45, 6922.

41 N. N. Greenwood and T. C. Gibb, Mössbauer Spectroscopy, Chapman and Hall, London, 1971, pp. 148-164.

42 J. Aussoleil, P. Cassoux, P. de Loth and J.-P. Tuchagues, Inorg. Chem., 1989, 28, 3051.

43 J. M. Clemente-Juan, C. Mackiewicz, M. Verelst, F. Dahan, A. Bousseksou, Y. Sanakis and J.-P. Tuchagues, Inorg. Chem., 2002, 41, 1478.

44 F. James and M. Roos, Comput. Phys. Commun., 1975, 10, 345.

45 A. Altomare, M. C. Burla, M. Camalli, G. L. Cascarano, C. Giacovazzo, A. Guagliardi, A. G. G. Moliterni, G. Polidori and R. Spagna, J. Appl. Crystallogr., 1999, 32, 115.

46 G. M. Sheldrick, SHELXL97, University of Göttingen, 1997.

47 L. J. Farrugia, J. Appl. Crystallogr., 1999, 32, 837.

48 C. K. Johnson, ORTEP, A Thermal Ellipsoid Plotting Program, Oak Ridge National laboratory, Oak Ridge, TN, 1965.

49 G.-C. Sun, Z.-H. He, Z.-J. Li, X.-D. Yuan, Z.-J. Yang, G.-X. Wang, L.-F. Wang and C.-R. Liu, Molecules, 2001, 6, 1001.

50 L. L. Koh, J. O. Ranford, W. T. Robinson, J. O. Svensson, A. L. C. Tan and D. Wu, Inorg. Chem., 1996, 35, 6466. 